mark, while the scheme is still far from being completed. Such figures clearly show what enormous sums of money are involved in land development on a large scale in this part of the world.

And with this observation I end my lecture. I said at the beginning that it would be quite impossible for me to deal exhaustively with the subject of "Problems of Development in Ceylon." I am well aware that, in this connection, I have done no more than skirt many problems, and that, in particular, I have hardly touched the human side of the problem of development, with its numerous aspects, such as the social organization and cultural growth of new communities, education, information, technical training, organization of the credit and co-operative systems, etc. But, as I have said, the nature of the subject is such as to enjoin restriction. And so I shall have to be content with the brief outline of it which I have given you.

\title{
SUMMARY OF A LECTURE ON THE PROBLEMS OF AGRICULTURAL DEVELOPMENT IN COLOMBIA ${ }^{1}$ )
}

\author{
A. LUYTJES \\ Director of the Royal Institute for the Tropics, Amsterdam
}

Colombia is situated both on the Atlantic Ocean (Caribbean Sea) and the Pacific Ocean. It extends from the equator to lat. $10^{\circ} \mathrm{N}$.; it is thirty-four times the size of the Netherlands, and has eleven to twelve million inhabitants. Its principal ports are Barranquilla and Cartagena on the Caribbean coast, and Buenaventura on the Pacific.

The country is divided from north to south by the Andes mountains, which split in the south into three chains, the Eastern, Central and Western Cordilleras, with snow-covered peaks some of which are nearly 5,500 $\mathrm{m}$ above sea level. These three chains are separated by the Rio Magdalena and Rio Cauca, which form deep valleys. The eastern half of Colombia is low-lying, and consists, in the south, of the densely forested Amazon region, and, in the north, of the almost treeless Orinoco region, the "llanos".

Owing to the great differences in altitude, great differences in climate are encountered. The mean annual temperature in the inhabited parts of the country ranges from $28^{\circ} \mathrm{C}$ in the lowlands to about $13^{\circ} \mathrm{C}$ in the inhabited highlands. The rainfall varies from $7,000 \mathrm{~mm}$ per year in the western coastal area to a few hundred millimetres in the north-eastern peninsula; the rainfall in the highlands is from 600 to $1,500 \mathrm{~mm}$ per year. There are two rainy seasons a year; but the intervening dry periods are, as a rule, not pronouncedly dry - there is a moderate rainfall even at those times.

Vegetation conditions vary strongly: primeval forest is encountered from the western slopes of the Western Cordillera to the sea, in the south-eastern Amazon region and in the middle reaches of the Magdalena river and its affluents. The high-mountainous area is almost entirely devoid of trees, like the llanos in the north-east. Severe erosion is encountered in places in the treeless high mountain region.

The ranges of mountains which cut through the country constitute formidable obstacles to communications, and endeavours are made to overcome this drawback, as far as is possible, by means of roads, railways, and a good air transport system. The problem of transport does indeed form one of the greatest difficulties in Colombia.

The population was originally Indian. In 1500 the country was conquered by the Spaniards, who settled chiefly on the high plateaux in the mountains, which, owing to

1) Paper presented at the Tropical Agricultural Days, 10 and 11 October, 1955 at Wageningen, Netherlands. See also: Reviews. 


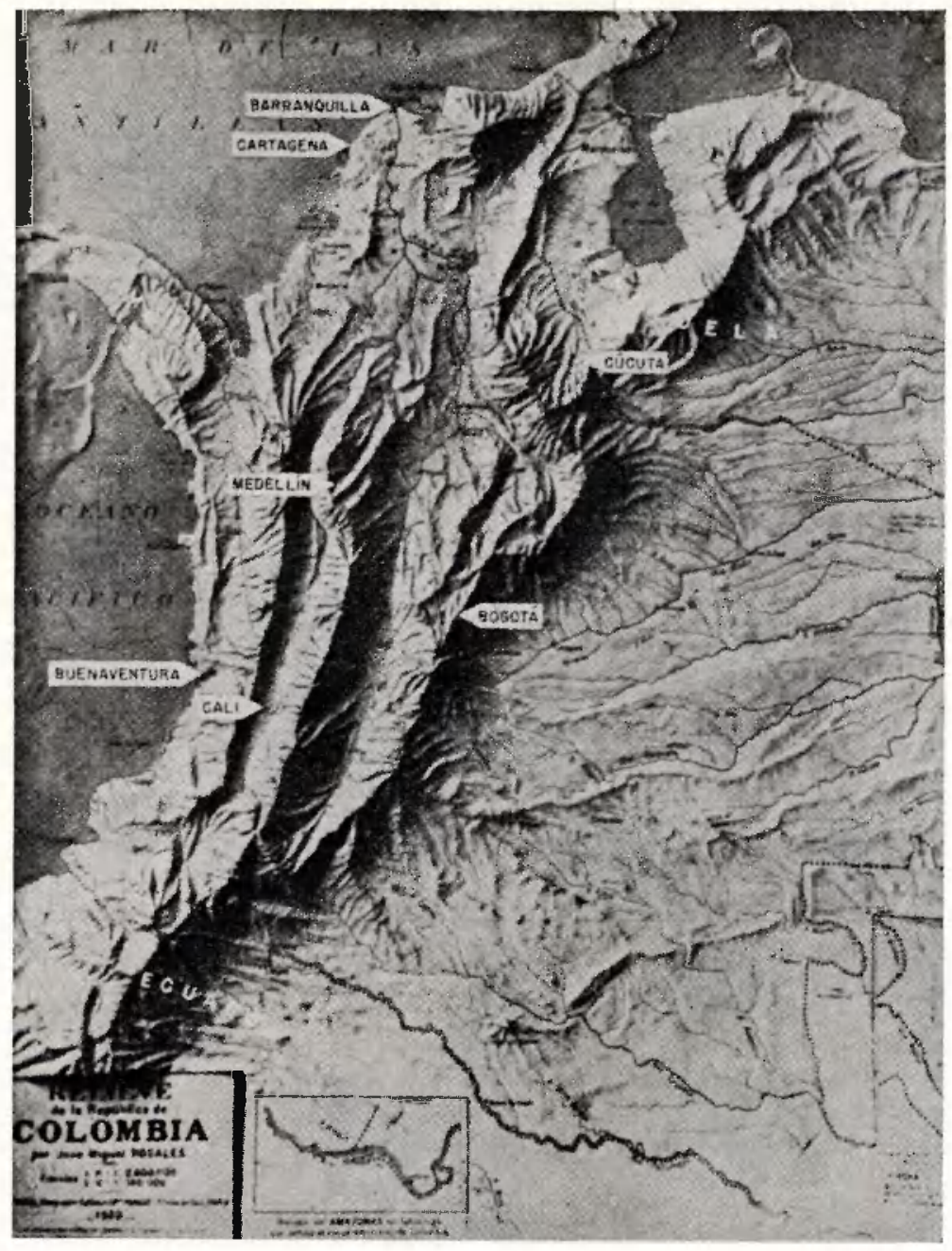

Fig. 1 Relief map of Colombia. (From : the Basis of a development program of COLOMBIA, REPORT OF A MISSION).

their cool climate and the absence of tropical diseases, were very attractive to the colonists. The Spaniards intermingled intensively with the original Indian inhabitants, the result being that pure-blooded Indians are difficult to find nowadays, outside a few reservations. The negro element in the population, which entered the country at the time of the slave trade, is now concentrated mainly in the coastal areas and the districts bordering them.

Owing to the establishment of the original Spaniards and their descendants on the high plateaux, a distinct system of large estates arose; the natives were forced back to the mountain slopes, where, in the main, a system of small holdings developed. Owing to the high rate of increase of the population, viz. about $2.4 \%$ per year, the mountain slopes became more and more densely populated, and consequently the contrast between the extensively run large estates on the plateaux and the crowded mountain slopes became more and more accentuated, and is now one of Colombia's social problems. The government is endeavouring to ameliorate the situation by settling people from the mountain slopes in lower-situated regions, and by providing them with technical education, to enable them to find employment in the country's large and small industries.

Spanish national characteristics have been preserved in Colombia, and find expression in a great sense of independence on the part of the people, and pronounced individualism. 
The land is subject to great political differences, which, in 1948, took the form of a civil war, the after-effects of which are still being felt. One consequence of the country's political instability is the lack of continuity in government services, owing to frequent change of officials; and this, only too often, prevents acquisition of the experience which is so badly needed.

Colombia is a unitary state, divided into Departments. For a long time there was conflict between federalist views and those favouring the unitary state. The first viewpoint still makes itself felt in the fact that the land's administration is quite considerably decentralized, and the departments enjoy a fairly high degree of independence.

Naturally, agricultural activities vary strongly in the country, all according to altitude and climate. In the lower-situated regions, typically tropical crops are encountered, such as rice, cassava, tobacco, etc.; in the higher regions crops from the temperate zones are found, such as wheat, barley, potatoes; maize is grown, in sundry varieties, in all parts of Colombia. In the region between the highlands and lowlands beans, sugar cane and coffee are found. Cattle-raising is carried on throughout the entire country - generally in the form of a fairly extensive beef-cattle industry, concentrated chiefly in the lowland and middle regions. Dairy farms are to be found round the big towns. The country is, however, inadequately supplied with milk and meat. A fairly large quantity of cattle is imported from foreign countries, including Holland.

Coffee accounts for eighty per cent of the value of the country's total agricultural exports. In addition bananas (United Fruit Company), tobacco and hides are also exported.

Home agriculture and industry are strongly protected by import duties; high prices are fixed on the home market in the endeavour to promote agriculture and industry as much as possible, so as to achieve self-sufficiency. This has extreme consequences, as an example of which mention may be made of the home wheat price, which is about four times that on the world market. By this policy of protection the standard of living of the country is raised, and export possibilities are severely limited. Export of coffee is possible because the product is grown on small family farms. The same can be said of tobacco.

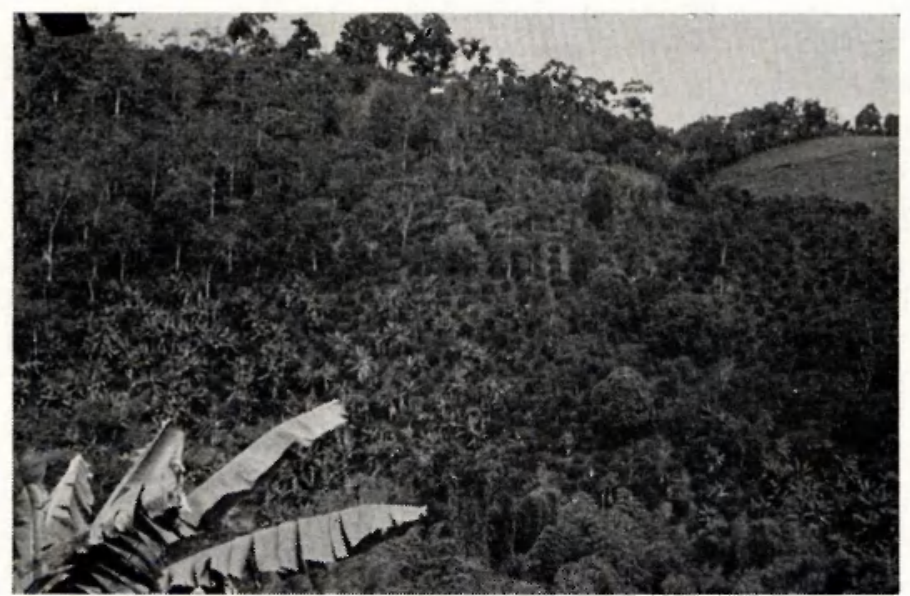

Fig. 2 The Native small holdings With COFfeE generally are situated in Steep MounTAINOUS REGIONS (Catchcrop: plantain, shade: guamo (Inga spec.).

In 1949, at the request of the government of Colombia, the International Bank for Reconstruction and Development sent a mission (the so-called CurRuE Mission) to the country, with the task of drafting an overall programme of economic development. This mission made recommendations, in a voluminous report, affecting agriculture, industry, transport, hygiene, education, generation of electric power, financial and commercial policy and government organization. Those recommendations have been partially put into effect, use being made of loans of foreign capital. The Interbank participated in this with loans 
for road and railway construction, electric power generation, and import of agricultural machinery (chiefly tractors), to a total amount of 79 million dollars.

The CuRrie Report did not go very deeply into the question of agricultural development. This fact prompted the Interbank, in consultation with the government of Colombia, to send a new mission to study the country's agriculture, of which mission Professor HELLINGa and the undersigned were members. The task of this mission was to draw up a ten-year plan for the agricultural development of Colombia. The present writer was made responsible for studying agricultural research, agricultural information and advice facilities (extension), forestry and erosion. The mission took as its first objective the increasing and improvement of agricultural production, in order, within a period of ten years, to keep the food supply of the population up to standard and, if possible, improve it, and to reduce the disparity between the home price level and that of the world market, thereby increasing export possibilities.

Examination of the governmental administrative apparatus which would have to be put into operation, in the first place, in order to achieve the object in view, proved the apparatus to function far from efficiently. The principal reasons which can be given for this are, lack of continuity in the staffing of government services, and stringent financial checking of all expenditure (preaudit), the consequence of which is an extreme sluggishness and lack of flexibility in carrying out operations. The outcome of this has been that various government activities have split off into autonomous organizations. The chief of these is undoubtedly the coffee-planters' organization, the Federación Nacional de Cafeteros, a powerful independent body with its own experimental station (Chinchina) and extension system, both of which work satisfactorily. Policy regarding the coffee industry is greatly influenced by the Federación. Comparable organizations, though on a smaller scale, exist in respect of cotton, tobacco and rice, while the idea of establishing others for other products is under consideration.

In this connection a special position is occupied by the Agricultural Credit Bank (Caja de Credito Agrario), with about 250 branches distributed throughout the country. In addition to granting credit this bank finances the purchase of, and sells, agricultural machinery, fertilizers, insecticides and fungicides; sees to the distribution of improved seed; carries out some irrigation works; carries out cocoa research and looks after publicity regarding cocoa; and, last but not least, finances all agricultural research.

These bodies, which, from the point of view of organization, sometimes look rather odd to us, and operate almost without coordination, were nevertheless considered by the mission to be acceptable under the circumstances, as they produce practical results.

After it had been found that agricultural research, under the direct management of the government, did not yield satisfactory results anyway, and that research concerning coffee, cotton, tobacco and cocoa had been conducted into independent channels, the Colombian Ministry of Agriculture sought contact with the RockEFELLER Foundation in connection with initiating research with regard to the chief people's food crops. In succession, responsibility for research into maize, beans, wheat, barley and potatoes was transferred to the RoCkefeller Foundation. Finally, in March 1955, all the branches of agricultural research which still remained under the Ministry of Agriculture were 
transferred to a new, semi-governmental organization, under the supervision of a government committee and under the direction of the Rockefeller FounDATION; when this took place all experimental stations and experimental gardens were also put into the hands of the new organization. The plan is financed by the government and the Rockefellen Foundation, via the Agricultural Credit Bank. In this way a mode of organization was found which freed the work the obstructive staffing and financial policy of the government.

The present writer had the impression that the work of the RockeFELLER Foundation in Colombia is on a high level, and is already beginning to bear fruit in the distribution of improved seed with the help of the Agricultural Credit Bank. The purpose of the new organization is gradually to train Colombian experts and then to hand the work over to them. This is, of course, a long-term programme covering many years.

Agricultural information and advice services show weak spots corresponding to those originally seen in the government's agricultural research system. These are aggravated by the fact that, in each of the country's administrative Departments, a state and a departmental agricultural information service operate side by side. For the purpose of improving these information facilities, help was accepted from the International Co-operation Administration ("Point Four" programme), which was entrusted with organization of the agricultural information service in one of the most difficult departments. In addition, the I.C.A. was also charged with extension of cocoa cultivation, and its assistance was also requested in organizing agricultural information work in the Cauca Valley. Here, too, the chief object in view is to give good guidance to the information service staffs, to enable the task of providing information to be gradually handed over to Colombian experts.

There are three places where agricultural training at university level is provided, viz., Medellin, Palmira and Manizales, from which about 25 agriculturists graduate each year. Extension and improvement of agricultural education would appear to be essential, in order to supply Colombia with the requisite agriculturists in connection with the need for increasing production. Secondary education in agriculture is almost unknown in Colombia, with the exception of one course at Chinchina, where pupils are trained to agricultural secondary-school standard. The virtual absence of a link in the form of people with agricultural secondary-school training, in agricultural research and, more particularly, in the agricultural information service, is a considerable obstacle to development of the work of improving the country's agriculture.

Forestry operations are chiefly fiscal ones, viz., collection of dues and keeping a check on them. In addition, increasing, but nevertheless still incidental, activity can be observed in the sphere of reafforestation; forest reserves are only very sporadically present, and inventorization of forest property has not yet taken place. Protection of the forests leaves a very great deal to be desired. Establishment of a forestry technical service is therefore greatly to be wished. Five years ago our fellow-countryman VAN BoTTENBURG worked in Colombia for the F.A.O., and made a number of recommendations for improving forest administration there. As a result of this a section for forestry was set up as part of the faculty of agriculture at Medellin, and forestry legislation was reformed. So far, however, little has been done to implement the new legal provisions. 


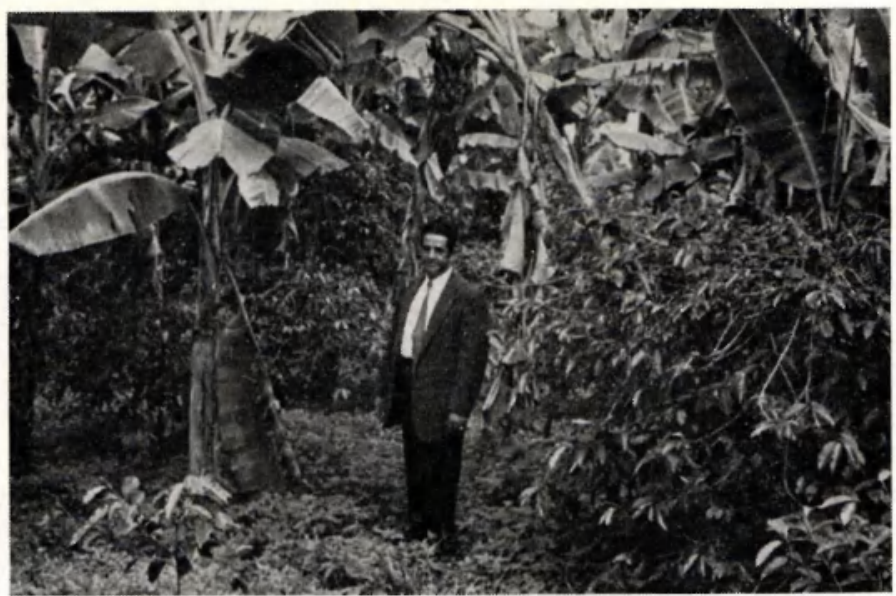

Fig. 3 Young native coffee plantation with plantaln as catcilciop.

Mechanization of agriculture, supply of fertilizer, and distribution of improved seed and planting material have made gradual headway in recent years, chiefly due to the progressive farmers with large estates on the high plateaux. It is via this class of farmers that better agricultural methods will find acceptance most easily, the example of the estates concerned forcing others in the neighbourhood to emulate them. A weak point in this development is the fact that, owing to the fall in cost prices on these farms, the gap between the big estates on the high plateaux and the small holdings on the slopes will be widened, and consequently special attention will have to be paid to the latter category of landowners.

Finally, care will have to be given to the development of multipurpose projects to increase agricultural production. An example of one such project, preparation of which is far advanced, is the Cauca Valley project. This has been placed under the administration of an autonomous corporation, the task of which is to effect further development of the region via flood control, drainage, irrigation, extension of the road network, generation of electricity, dissemination of advice and information on agricultural subjects, and reafforestation. The adviser to the project is David LiLIENTHAL, known for his work on the Tennessee Valley project.

It will be possible to carry out similar multi-purpose projects in various parts of the Andes highlands, for instance on the Bogotá plateau. The agricultural mission paid careful attention to this point.

Summing up, it can be said that Colombia is a land of many possibilities and many problems. The fact that, in spite of the political disturbances of the last ten years and the increase in the population by $2.4 \%$ per year, a general rise in the welfare level is nevertheless evident, leads one to expect that, provided further measures are taken, it will be possible for this upward tendency to be continued. However, in order to achieve this, reorganization in various spheres will be necessary. Moreover, for further development it will be impossible to do without aid from abroad, in the shape of imported experts and capital. 